\title{
The Integration of Urban and Rural Development Policy Research
}

\author{
Yi Guangying \\ Department of Marxism, Liaoning Shihua University, Liaoning Province Fu Shun 113001, China \\ yiguangying@sina.com
}

\begin{abstract}
The idea of integrating urban and rural development is an important component of agricultural economic theory of socialism of Marx's theory of innovation China and the Chinese characteristic, this theory has a profound domestic and international background. The integration of urban and rural development thought keeping pace with the times, according to the actual situation of continuous innovation.
\end{abstract}

Index Terms - The integration of urban and rural development, Innovation, The scientific outlook on development

\section{Introduction}

The strategic thought of urban-rural integration, constitutes the important content of the party's theoretical innovation. Since the party's 16 big, obvious contradiction of urban and rural development in our country, in order to break the urban-rural dual structure, solve the problem of "agriculture, rural areas and farmers", put forward the development strategy of urban and rural integration and reform measures, "to promote the integration of urban and rural development, solve the problem of good agriculture rural farmers is the party work priority, the integration of urban and rural development is to solve the" agriculture, rural areas and farmers' question basic way."[1] - The communist party of China the urban-rural integration of Marx and Engels thought creatively combined with China's actual economic and social development, formed the system and the integration of urban and rural development thought with Chinese characteristics.

\section{The background of the integration of urban and rural development thought}

Integration of urban and rural development thought is the theory of socialism with Chinese characteristics agricultural economy important constituent, is based on the primary stage of socialism in our country basic national conditions, China's economic and social development practice, draw lessons from foreign experience in urban and rural development, to adapt to the new requirements of development, put forward a series of integration of urban and rural development thought.

The integration of urban and rural development thought is based on our country city and countryside dual structure, urban and rural development uncoordinated. Due to the traditional economic system, the different urban and rural policy fragment, etc. The influence of various factors, which leads to the highly development of coordination, severely restricts the economic and social development. Entering the 21 st century, especially the third plenary session of the 16th, our party has more than 50 years of development experience is summarized, at the current stage of development on the basis of the actual, in order to adapt to the socialist modernization with Chinese characteristics and the need of building a welloff society in an all-round way, put forward the concept of scientific development.

Integration of urban and rural development thought is the summary of the experience, the world development of western urban and rural development theory on the basis of the absorption and reference. Since the 19th century, with the rapid rise of the industrial revolution in Europe and the United States, the enclosure movement forced a large number of landlost farmers began to flock to the city, the opposition between urban and rural areas, industrial and agricultural opposition began to emerge, led to the expansion of the city and the life quality is deteriorated. In the 21 st century, countries all over the world pay more attention to the urban and rural network development model, which emphasizes the close ties between rural and urban areas, theories about urban and rural coordination development.

With the deepening of the coordinated development of urban and rural areas thought and internationalization, the countries of the world, especially the integration of urban and rural development in developing countries on the theory and practice of exploration, as the party's thinking of the integration of urban and rural development provides an important source of ideas. In the theory of urban and rural development, western scholars put forward the overall concept of urban and rural development, segmentation, coordination; Facing the trend of the coordinated development of urban and rural areas, the world of our party to absorb the essence of the western theory of urban and rural development, formed the systematic thought of the integration of urban and rural development, complied with the trend of the integration of urban and rural development in the world.

\section{Since the 16th national congress of the party's theoretical basis of the integration of urban and rural development thought}

Urban and rural development view is the integration of urban and rural development of the party of Marxism thoughts of theoretical basis.

First of all, since the 16th national congress of the party's integration of urban and rural development thought theoretical innovation of sanitization of Marxism, inheriting and developing the urban and rural integration ideas of Marx and Engels. Marx and Engels on the nature of capitalist society of historical materialism analysis, attaches great importance to the relationship between urban and rural areas, and reveal the 
unity of urban and rural areas to antagonism between urban and rural areas to urban and rural the development of the new fusion rule. Demonstrates that caused by social division of labor of agriculture and industry separation, thus lead to separation and conflict between urban and rural areas. And put forward in the communist manifesto, "almost all the most advanced countries to combine agriculture and industry, prompting opposition between urban and rural areas gradually eliminated."[2] Marx and Engels think that urban-rural integration is a long historical process, in order to realize the integration between urban and rural areas, population to average distribution throughout the country, the urban and rural way of life, the combination of the advantages of establish close contact and industrial production and agricultural production, at the same time should be adapted in the traffic.

Since the 16th national congress of the party's integration of urban and rural development thought and MAO Zedong, ding Xiaoping's thinking on urban and rural development is in line. Since the founding of the people, MAO Zedong and ding Xiaoping in the construction of socialism with Chinese characteristics, the Marxist concept of the urban and rural areas and the reality of China, summarizes a series of step by step for China's national conditions of urban and rural development of ideas, both, deepen and continuous development, formed the systematic thought and scientific integration of urban and rural development system, covers various parts of the integration of urban and rural development, and to increase the integration of urban and rural development thought to the national development strategy level, promote the formation of the integration of urban and rural development in China, promoting the development of social productivity, the construction of a harmonious society and the realization of building a well-off society in an allround way.

After the founding of new China, MAO Zedong emphasized the important status and role of agriculture, and put forward the "there is no agriculture industry" ideas of urban and rural, and decided to take agriculture as the foundation of the national economic development, industrial development depends on agriculture, puts forward the idea of industry and agriculture simultaneously at the same time. Since China's reform and opening up, ding Xiaoping for close contact and development of the relationship between urban and rural areas in our country, put forward the agriculture is the foundation and fundamental, industry support agriculture, promote agricultural modernization thoughts. Since the 16th national congress of our party to inherit and develop MAO Zedong, ding Xiaoping's thinking on urban and rural development, attaches great importance to the basic role of agriculture and the coordinated development of urban and rural areas, in today's world to fully understand the urban and rural development and the situation of our country, on the basis of correct understanding, put forward the strategic thought of the national development of urban and rural integration, fully reflects our party's deeper understanding to the law of urban and rural development and development. The integration of urban and rural development thought is based on the dialectical materialism and historical materialism, on the basis of the complete system of thought, from set out actually, incisive summary in social production and life practice. The integration of urban and rural development idea is put forward according to the principle of practical strategic thinking.

\section{The party's basic content and process of the integration of urban and rural development thought}

"Urban-rural integration" as a national development strategy in 2002 was the first to clear in the party's 16 big reports, mainly aimed at the time of the "three rural problems" strategic decision is put forward, in order to solve the poverty as soon as possible, improve the rural economy, agriculture, urban and rural construction and the development and coordination of the planning. "The rural economy flourishes and speeds up urbanization. Urban and rural economic and social development as a whole, the construction of modern agriculture, developing the rural economy and increase farmers' income, the major task of building a moderately prosperous society in an all-round way."[3]The social economic development soon, but continued to grow, the trend of widening gap between urban and rural areas in our country has become the urban and rural income distribution gap among countries. According to expert analysis, the trend of gradually widening gap between urban and rural areas is not conducive to the rural economy and farmers get rich, and affect social public distribution, cause many social contradictions, therefore, should pay more attention to the development of farmers, and the transfer of rural surplus labor to non-agricultural and urban, is the inevitable trend of industrialization and modernization. To improve the level of urbanization gradually, adhere to the coordinated development of big and medium cities and small towns and, the road of urbanization with Chinese characteristics."[3]

Industry nurture agriculture and cities support the countryside, the realization of industry and agriculture, urban and rural harmonious development, is the logic starting point of the integration of urban and rural development thought. Adhere to the "industry nurturing agriculture and cities support rural" thoughts, make full use of the impetus to the development of agricultural economy, industrial economy attaches great importance to the role of promoting rural revitalization of urban development. In September 2004, the party's fourth plenary of sixteen session put forward two universal trends: it is in the early stage of industrialization, agriculture to support the development of industry trend; second, in a certain period of industrialization, industry nurture agriculture and cities support the countryside, realize the industry and agriculture, urban and rural harmonious development. This thesis put forward for the formation of the integration of urban and rural development thought of the theory, the principle of the new relationship between urban and rural areas and policy, shows that the new relationship between the workers and peasants and urban-rural integration development strategy of scientific theory of substantive issues 
resolved, shows that our party according to the actual development level of modernization, understanding of the law of urban and rural development, the emphasis on the urban and rural development of our country into the "hometown to work, to the city belt agriculture" in the new stage.

Strengthen the position of agriculture as the foundation of the economy, and promote the development of ecological agriculture, the constant virtuous cycle, graceful landscape ecological system, functional diversity, a new type of agriculture, rural and urban areas is the basic standpoint of the integration of urban and rural development thought. The integration of urban and rural development is based on the development of agriculture, only improve the agricultural productivity, to promote the coordinated development of the agricultural modernization and industrial modernization." build high ecological value of agriculture and biotechnology industry system in our country, the agricultural high value transformation of industry system, constant virtuous cycle, graceful landscape ecological system, functional diversity, a new type of agriculture rural and urban areas. [4], therefore, in the production practice in our country should carry out the integration of urban and rural development thought of hub junta, seize the important strategic thought of agricultural development, in the construction of urban and rural integration, attaches great importance to the ecological agriculture development, promote the integration of urban and rural economic and social development.

Establish the integration of urban and rural economic and social development of systems and mechanisms, the road of urbanization with Chinese characteristics, and construction of new socialist countryside in the integration of urban and rural development thought. In the 17th session of the party's central committee third plenary meeting said: "to form a mutually promote urbanization and new rural construction mechanism." [5] Urbanization and build a new socialist countryside is the integration of urban and rural areas two wheels, only they are neck and neck, to jointly promote the development of urban and rural integration. First of all, "proceeding from its national conditions, adhere to the coordinated development of big and medium cities and small towns and to the road of urbanization with Chinese characteristics, continuously improve the level of urbanization with the economic and social development." [6] combined with the domestic and international situation at that time, the scientific judgment in our country urbanization level is not high, only the development of township enterprises, optimize the structure of villages and towns economy, speed up the urbanization level, in order to absorb the rural surplus labor force, adjusting rural economic structure, reduce agricultural large population too much, optimize the structure of industry of society, improving farmers' production and living ways, improve the whole quality of farmers, narrow the differences between town and country, eliminate the urban-rural dual structure, promote the integration of urban and rural development. Party eighteen big report stressed: "hang on industry nurturing agriculture and cities support rural and giving more, taking less and allowing flexibility policy, intensify Japanning its rich peasants policy, make the broad masses of farmers equal to participate in the modernization process, share the achievements of modern." [7]

Increasing Japanning rich peasants policy efforts, let farmers equal to participate in the modernization process, share the achievements of modern, embodies the "peopleoriented" ideas of the integration of urban and rural development. The ultimate goal of the integration of urban and rural development is to realize person's full scale development, adhere to the people-oriented, is to narrow the gap between urban and rural people's various, improve the comprehensive quality of people and benefit the people, promote the urban and rural people's all-round development. Our party pays special attention to the fundamental problem of farmers' own development. But the reality is that the farmers' income is low, increasing farmers' income is more difficult. Therefore, the integration of urban and rural development strategic thought to increase farmers' income as the central task of the agricultural and rural work. The third plenary session of the sixteenth central committee, the CPC central committee has adopted a series of major and specific measures to care about the farmers concerns, lighten the burden on farmers, such as implements various subsidies for farmers, such as grain direct subsidies, subsidies for growing superior seed varieties and purchasing agricultural machinery and tools and general subsidies for agricultural supplies. In 2006, the country abolished the agricultural tax regulations, this means that for more than two thousand years in our country, the "emperor" tax be completely canceled, reduce the burden of more than 900 million farmers, benefit the broad masses of farmers. Party eighteen big report stressed: "hang on industry nurturing agriculture and cities support rural and giving more, taking less and allowing flexibility policy, intensify Japanning its rich peasants policy, make the broad masses of farmers equal to participate in the modernization process, share the achievements of modern."

Adhere to the "people-oriented", to the comprehensive development of farmers for the purpose of urban-rural integration. Party attaches great importance to the all-round development of the farmers problem, and take measures to increase vocational skills training for rural labor force, the development of rural basic education, vocational education and continuing education, improve the comprehensive quality of farmers, strengthen farmers' quality survival and development ability, multi-channel space for farmers to create jobs, to lift the various discriminatory provisions on employment of farmers into the city, protecting the rights and legitimate rights and interests of farmers. Balance urban and rural social endowment insurance system, to promote the effective docking system between urban and rural areas, constantly improve the level of security, narrowing the gap between urban and rural people, and realize the integration of urban and rural development.

Since the 16th national congress of the party's integration of urban and rural development thought has important theoretical significance and practical significance. In theory, the integration of urban and rural development thought 
enriched and developed the thought of Marx and Engels urban-rural integration development, practice by the separation of urban and rural areas to urban and rural development theory, enrich the scientific concept of development, is another theoretical innovation of sanitization of Marxism. First of all, the integration of urban and rural development thought of Marx and Engels thought about the development of urban and rural integration further enrich to balance urban and rural economic, political, ecological, cultural, and social harmonious development, emphasis on new workers and peasants to form the urban and rural, urban and rural relationship. Second, the integration of urban and rural development thought enriched and developed with kiang semen as the core of the party's third generation of collective leadership of urban-rural interaction development thought, the integration of urban and rural development theory to improve to a new height. In the end, the party's integration of urban and rural development thought do theoretical preparation for the social development of our country.

In practice, the integration of urban and rural development ideas put forward many new judgment and measures, such as increasing financial capital investment of rural infrastructure, one thousand party hundreds of promoting the steady increase in rural incomes, transfer of rural surplus population, broadening the employment channels, farmers to establish rural social security system, the rights and interests of migrant workers protection system and the social public service system and so on, to promote the urbanization and new rural construction, gradually eliminate the urban-rural dual system, to curb the further widening gap between the urban and rural areas. Found feasible effective way for urban and rural development. First of all, the party to promote the integration of urban and rural development thought has important guiding significance to the construction of well-off society in our country. The integration of urban and rural development thought is more equal relationship between urban and rural areas, change the policies of the past "urban bias", pay more attention to agriculture, rural areas and farmers, and social multiple point of building a well-off society in all aspects to provide a practical and effective measures. Second, the integration of urban and rural development thought conforms to China's economic and social development law and trend, helps to solve the current contradictions in the urban and rural development of our country and the problem of "agriculture, rural areas and farmers", narrow the gap between urban and rural, eliminate the urban-rural dual structure, to achieve the integration of urban and rural development in our country, pointed out the direction to open up a new prospect of the cause of socialism with Chinese characteristics and building a harmonious socialist society has important

\section{Acknowledgment}

The integration of urban and rural development thought keeping pace with the times, according to the actual situation of continuous innovation, such as industry back feeding agriculture, city support the countryside, the industry and agriculture, city and rural harmonious development of thinking; urban and rural economic and social development, promote the development of ecological agriculture, the formation of the idea of sustainable development is the integration of urban and rural ecosystem sustainable benign loop; increase the strong agricultural Honing rich peasants policy strength, let the farmers equal participation in the process of modernization, share in its fruits, go China characteristic of urbanization and the building of a new socialist countryside with the urban and rural social development integration thought.

\section{References}

[1] Unswervingly along the path of socialism with Chinese characteristics Strive to build a well-off society in an all-round way, report on the eighteenth national congress of the communist party of China. Beijing: people's publishing house, 2012, pp. 21.

[2] Marx and Engels, Marx and Engels anthology (volume 1), 1995, pp. 5.

[3] Building a well-off society in an all-round way and create a new situation in the cause of socialism with Chinese characteristics in report on the 16th national congress of the communist party of China. Beijing: People's Daily. 2002, pp. 11-18.

[4] On the 15th of the Chinese academy of sciences academician, the tenth academician of Chinese academy of engineering conference speech, Beijing: people's publishing house, 2010, pp. 9.

[5] Central literature research, the important literature since the 17th Ed:, Beijing: central literature press, 2009, pp . 677.

[6] HuJingtao, was established in Shenzhen special economic zone on the 30th anniversary celebration speech, people's publishing house, 2010, pp. 10. 